\title{
Review of Relationship between Intellectual Capital and
}

\section{Organizational Justice}

\author{
Nour-Mohammad Yaghoubi \\ Department of Management, School of Management and Accounting \\ University of Sistan and Baluchestan \\ Zahedan, Zip Code: 9816745685, Iran \\ E-mail: yaghoobinor@yahoo.com \\ Habibollah Salarzehi \\ Department of Management, School of Management and Accounting \\ University of Sistan and Baluchestan \\ Zahedan, Zip Code: 9816745685, Iran \\ Jamshid Moloudi \\ Public Administration, University of Sistan and Baluchestan \\ Zahedan, Zip Code: 9816745685 , Iran \\ Esmaeil Yaghoubi \\ Department of Maritime Business \& Management, School of Management and Human Sciences \\ Chabahar Maritime University \\ Chabahar, Zip Code: 9816745685 , Iran
}

\begin{abstract}
The study was planned to ascertain the relationship between intellectual capital and organizational justice. In present research the sample size consists of 141 employees (49 women and 92 men) that were selected at random from East Azerbaijan Documents and realty organization and East Azerbaijan biographic organization of Tabriz in Iran. Organizational justice and Bontis intellectual capital questionnaires were applied to collect the data. Pearson correlation coefficient, Enter regression was used to analyze the data. The results illustrated that there is positive significant correlation between the mean scores of organizational justice and intellectual capital dimensions namely human capital, costumer capital and structural capital and total scores of social capital $(\mathrm{p}<0.01)$. The results of Enter regression showed that predictor variables significantly (human capital and customer capital) have determined $62.5 \%$ of the variance of organizational justice together. But other variable did not predict the intellectual capital. The results of present study reveal that we should pay specific attention to percept and improve intellectual capital and organizational justice, because both are essential for all organizations.
\end{abstract}

Keywords: Organizational justice, Intellectual capital, Human capital, Costumer capital, Structural capital

\section{INTRODUCTION}

Generally, there are three types of capitals in every organization namely: natural capital, physical capital and human capital, that all of them have affected on justice performance (Ambrose, 2002). But, today, have come to conclusion that social and organizational development depends on increasing intellectual capital levels in every place (Zhang \& Fung, 2006). However, intellectual structures of organization have deep effect on justice structure in every organization. In the other hand, suddenly, the employee satisfies were not depended on traditional factors as salary and working place, but, it is influenced by quality of human justice among 
collaborators. According to Gui (2000), this capital related can help to organizational performance more than other capitals as equipment and machinery. As such, growing attention to the role of intellectual norms, that causes to develop creativity, innovation, justice and etc. in organization. Also, the use of intellectual capitals of organization can create a participatory environment in this uncertainly situations. Since, the injustice caused to being marred of human dignity and reducing intellectual capital and national commitment and health threat (pourezat, 2003). And perception of organizational justice, is a basic recruitment to proper function of organizations and individual satisfy of employees, that to play an important role in shaping their attitudes and behavior (Lambert, 2003). Therefore, the original question of the present study was review of relationship between organizational justice and intellectual capital. This question was studied by test decimations of intellectual capital on organizational justice.

\section{LITERATURE REVIEW}

Organizational justice: justice is an abstract concept that there are various interpretations, when this concept is used in the environment of organization that is called as organizational justice. According to Greenberg (2000), perception of organizational justice is necessary for effectiveness of organizational performance and satisfaction of employees in organizations. Term of organizational justice, for the first time was expressed by Greenberg in 1970. Fernandes and Awamleh (2006) have expressed Greenberg's quotes that organizational justice refers to fair treatment with employees. And usually it is included three different elements that is as follows: distributive justice, procedural justice and interactional justice.

Distributive Justice: Distributive justice involves the receiver's views on how their outcome compares to a referent's outcome, the outcome of another employees (Organ, 1988). Asserts, Debates about the criteria -such as status, seniority, productivity, effort, and need-that should determine salary have to do with distributive justice. In this illustrative example, Organ alluded to the three rules of distribution, a further division of distributive justice: Equity, Equality, and Need.

Distributive fairness reflects how fair employees in an organization perceive the actual allocation of outcomes they receive to be (Burney, Henle and Widener, 2008). Problems with distributive justice may arise if employees feel something negative cannot be avoided, when everyone cannot receive the same thing or what they each want, and when valuable resources or outcomes are scarce (Chory and Westerman, 2009).

Procedural Justice: Procedural justice deals with the procedures that the organization uses to come to a decision. Organ (1988) refers to this type of justice as the way in which an organization applies the relevant criteria to arrive at a decision. (Muchinsky, 2000) argued that a decision is procedurally just if it is consistent, "without personal bias, with as much Accurate information as possible, and with an outcome that could be modified. Consider two individuals, identical in every job-relevant aspect. Suppose they were both up for their performance review, which is the company's basis for pay increase. If one received a greater increase than the other, the recipient of the lesser would view the procedure as unjust. The recipient of the higher increase may also view the procedures as unjust, but would probably be less apt to raise any grievances.

Procedural justice is characterized by the fairness of the processes that are used to determine what outcomes are used, how they are distributed, and to whom the outcomes are given. Suggested attributes of organizational procedural justice include freedom from bias, accuracy, consistency, representation by stakeholders, correction of errors and ethical consistency (Cropanzano and Stein, 2009).

Interactional justice: Interactional justice is the third type of organizational justice and concerns the perception of fairness in procedural treatment of others (Krings and Facchin, 2009), Issues with interactional justice can arise when employees are lied to, judged unfairly and denied privacy or respect (Cropanzano and Stein, 2009). A low level of interactional justice may be related to a greater likelihood of sexual harassment. A study suggested that existing individual differences in personality and hostile behavior influence how individuals react to unfairness in the organization (Krings and Facchin, 2009) How employees perceive the validity and relevance of their performance ratings at their jobs relates to employees' perceptions of procedural justice; by using a rating system that is, and perceived as valid enhance the employees' perceptions of organizational justice (Burney, Henle and Widener, 2008).

Intellectual capital: Although increasing in importance in the economy, IC is a complex concept and therefore difficult to define. This is evident in the number of different definitions existing in the literature (Sujan \& Abeysekera, 2007) ranging from a subset of intangible capital (Hunter et al., 2005), the difference between the market value and the book value of a firm (Ordonez de Pablos, 2005) and knowledge based resources that contribute to the creation of a competitive advantage for the firm (Ordonez de Pablos, 2005). For this study, IC is defined to include all the knowledge-based intangible processes and assets which are not normally shown on the 
balance sheet, and can be leveraged to give rise to future value (Roos et al., 1997). Perhaps an easier way to describe IC is by its components. A tripartite framework used in many of the prior ICD studies (Petty \& Cuganesan, 2005) is that originally suggested by Sveiby (1997) and consisting of internal (structural) capital, external (relational/customer) capital, and human capital (employee competence). Internal capital refers to "the knowledge embedded in organizational structures and processes" (Petty \& Cuganesan, 2005) and consists of two main elements, intellectual property (e.g. copyrights, patents, and trademarks) and infrastructure assets (values, systems and processes used in day-to-day activities). On the other hand external capital category consists of the relationships a firm has with outside stakeholders (Petty \& Cuganesan, 2005) such as customers and suppliers, and incorporates relationship methods such as brands, reputation and business collaborations. Finally human capital refers to "the skills/competences, training and education, and experience and value characteristics of an organization's workforce" (Petty \& Cuganesan, 2005). Human capital builds the internal structure, and these two categories of capital are mutually reinforcing within an organization (Edvinsson \& Malone, 1997).

Earlier research was in the main descriptive, detailing the level of internal, external and human capital voluntary disclosure exhibited in the annual reports of individual countries (Guthrie \& Petty, 2000; Brennan, 2001; Goh \& Lim, 2004; Abeysekera \& Guthrie, 2005) and in general the findings indicated that the levels of voluntary IC disclosure are low worldwide. In addition, despite differing firm selection criteria and measurement unit in the content analysis, the studies consistently showed that external structure capital was the most frequently reported IC category, usually followed by internal structure capital, with human capital the least frequent (Whiting \& Miller, 2008). The OECD (1999) defines intellectual capital as 'the economic value of two categories of intangible assets of a company' - organizational and human capital. Wright et al (2001) argue that intellectual capital is a factor that includes human capital, social capital and organizational capital. For Nahapiet \& Ghoshal (1998), intellectual capital refers to the knowledge and knowing capability of a social collectivity, such as an organization, intellectual community, or professional practice. There is a lack of clarity surrounding these and related terms, with numerous definitions abounding. In one study, Gratton \& Ghoshal (2003) argue that intellectual capital is part of human capital, that is, human capital subsumes intellectual capital, and also includes within it social capital and emotional capital. For most commentators, however (e.g. Harvey \& Lusch 1999) intellectual capital has a broad sweep and includes human capital as one of its key dimensions.

Human capital: The prevailing definition of organizational human capital adopts a competence perspective (Elias \& Scarbrough, 2004). Flamholtz and Lacey (1981) emphasized employee skills in their theory of human capital. Later researchers expanded this notion of human capital to include the knowledge, skills and capabilities of employees that create performance differentials for organizations (Nahapiet \& Ghoshal, 1998). Parnes (1984) defined human capital as that which embraces the abilities and know-how of men and women that have been acquired at some cost and that can command a price in the labor market because they are useful in the productive process."

Social capital: According to Nahapiet \& Ghoshal (1998), the central proposition of social capital theory is that networks of relationships constitute a valuable resource for the conduct of social affairs. Much of this capital is embedded within networks of mutual acquaintance. Social capital, it is argued, increases the efficiency of action, and aids co-operative behavior (Nahapiet \& Ghoshal 1998). Gratton \& Ghoshal (2003) argue that social capital is based on the twin concepts of sociability and trustworthiness: 'the depth and richness of these connections and potential points of leverage build substantial pools of knowledge and opportunities for value creation and arbitrage.

Organizational capital: The principal role of organizational capital is to link the resources of the organization together into process that creates value for customers and sustainable competitive advantage for the firm (Dess \& Picken 1999).

Bontis (2001) was said that there are three elements that are proposed as encompassing intellectual capital, as follow: Human Capital, Structural Capital and Customer Capital. Human capital can be decrypting as the firm's collective capability to extract the best solutions from the knowledge of its individuals. Structural capital can be thought of as the firm's organizational capability to meet market requirements. Finally, Customer capital refers to the end-user's satisfaction and loyalty to the organization. Figure (1) is showed dimensions of intellectual capital by perspective of Bontis.

Pourezat and Golipour (2008) were studied about the structure barriers of organizational justice. The result of theirs study was illustrated that Organizational structure has direction impact on justice. So the appropriate organization structure has positive effect on organization justice altogether. But the nature, intensity and weakness of that effect is ambiguous. Also, Golipour and Moshabaki (2006), were studied about the role of 
social capital on create intellectual capital in organization. The result of theirs study was showed that there is a positive significant between social capital and intellectual capital. Amirkani and Pourezat (2006) continued the research of Golipour and Moshabaki (2006), were studied about review of relationship between social capital and organizational justice. The reason of theirs study was illustrated that social capital has positive impact on organizational justice. Also, according to Wright, Dunford and Snell (2001) intellectual capital has consisted from three factors that are as follows: human capital, social capital and organizational capital. So, Can be said that intellectual capital has impact on organizational justice, this impact can be positive and negative. We intend to investigate whether this effect is positive or negative.

\section{RESEARCH QUESTIONS}

1) Is there any significant correlation between dimensions of intellectual capital and organizational justice?

2) What is regression equation of organizational justice on dimensions of intellectual capital?

\section{RESEARCH METHODOLOGY}

\subsection{Sample}

This Study Was Descriptive-correlation. The sample size of the present study consists of 141 employees (49 women and $92 \mathrm{men}$ ) that were selected at random from East Azerbaijan Documents and realty organization and East Azerbaijan biographic organization of Tabriz in Iran.

\subsection{Tools Used}

Intellectual capital was assessed by organizational justice Questionnaire that was published with 18 items to measure organizational justice in organization. Its reliability was reported 0.842 . Intellectual capital was assessed by Bontis IC Questionnaire that was published with 43 items in 2001 to measure intellectual capital in organization. Its reliability was reported 0.916 . Both of them are in 5 point Likert-type scale ranging from "I strongly disagree" to "I strongly agree". Data analysis was carried out by using the statistical program packages SPSS.

\section{RESULT}

The results of table.1 show that there is positive significant correlation between the mean scores of organizational justice and intellectual capital dimensions namely: human capital, customer capital, structural capital and total scores of intellectual capital ( $\mathrm{p}<0.01)$. (See the table.1 in appendix).

As seen in table. 2 the significant predictors (intellectual capital) have determined $62.5 \%$ of the variance of Intellectual capital together. (See the table.2 in appendix)

As seen in table.3, at first step customer capital has satisfied the entrance criterion of the regression as a very important predictor $(B e t a=0.443$ ). At second step human capital has satisfied the entrance criterion predictor $(B e t a=0.242)$. But other dimensions intellectual capital namely structural capital could not satisfy the entrance criterion of the regression, then regression equation of the regression of organizational justice on organizational intelligence and its dimensions is as fallow:

Intellectual capital $=0.443$ (customer capital) +0.242 (human capital).

(See the table.3 in appendix).

\section{CONCLUSION}

Studies are indicated that judgment of the individuals depends on rate respecting justice in organization. Also, when people feel that outcomes and procedures are unfair, probably, will be bad performance in organization. Greenberg and Baron (2000) believed when people feel that organizational behavior is unfair, then, increases aggressive and dangerous behavior in organization.

According to the results of table (1) can be said that there are positive coronation between organizational justice and intellectual capital and its dominations in $(\mathrm{p}<0.01)$. Also, according to the results of table (2) can be concluded that significant of predictor variables namely (human capital, customer capital and structural capital) is $62.5 \%$ variance of organizational justice. Also, according to results of table (3) can be told that significantly in the customer capital is more than human capital. This means that we should pay attention to customer capital in organization. Because, according to Bentis (2001) customer aspect is much more important than other aspects of intellectual capital. Also, the findings of the present study are in conformity with researches of Pourezat and Golipour (2008), Golipour and Moshabaki (2006), Amirkani and Pourezat (2006), Wright, Dunford and Snell (2001). 
Various researches of Bontis (2001) showed which organizations have high intellectual capital, justice, generally commitment, competitive advantage and etc. are high too. And this capital causes to treated effective in organization.

Therefore, all of organizations, both generally and specially, enhance the level of intellectual capital, because with higher intellectual capital, organization justice increases too. Thus, if this two organizations and even other organizations want to achieve organization justice, should invest as acceptable both social capital and intellectual capital.

\section{References}

Abeysekera, I., \& Guthrie, J. (2005). An empirical investigation of annual reporting trends of Intellectual capital in Sri Lanka. Critical Perspectives on Accounting, 16, 151-163.

Ambrose, L. (2002). Contemporary Justice Research: A new look at familiar questions. Organizational Behavior \& human decision processes, Vol. 89, Issue: 1 .

Bontis, N. (2001). Managing organizational knowledge by diagnosing intellectual capital: framing and advancing the state of the field. Idea Group Publishing, 271-301.

Brennan, N. (2001). Reporting intellectual capital in annual reports: evidence from Ireland. Accounting, Auditing and Accountability Journal, 14, 423-436.

Burney, L. L., \& Henle, C. A., \& Widener, S. K. (2008). A path model examining the relations between strategic performance measurement system characteristics, organizational justice and extra and in role performance. Accounting, Organizations, and Society, 34, 305-321.

Chory, R. M., \& Westerman, C. Y. K. (2009). Feedback \& Fairness: The Relationship between Negative Performance Feedback and organizational Justice. Western Journal of Communication, 73, 157-181.

Cropanzano, R., \& Stein, J. H. (2009). Organizational Justice and Behavioral Ethics: Promises \& Prospects. Business Ethics Quarterly, 19, 193-233.

Dess, G.D., \& Picken, J.C. (1999). Beyond productivity: How leading companies achieve superior performance by leveraging their human capital. New York: American Management Association.

Edvinsson, L., \& Malone, M. S. (1997). Intellectual Capital: The Proven Way to establish your Company's Real Value by measuring its Hidden Brainpower. USA: HarperCollins Publishers Ltd.

Elias, J., \& Scarbrough, H. (2004). Evaluating human capital: an exploratory study of management practice. Human Resource Management Journal, 14, 21-40.

Fernandes, C., \& Awamleh, R. (2006). Impact of organizational justice in an expatriate work environment. Management Research News, Vol. 29, Issue: 11, 701-712.

Flamholtz, E. G., \& Lacey, J. M. (1981). Personnel management, human capital theory, and human resource accounting. Los Angeles, CA: Institute of Industrial Relations, University of California.

Glichpour, B., \& Mosabaki, A. (2006).The role of social capital in create of intellectual capital. Journal of knowledge management, 75 (In Persian).

Goh, P. C., \& Lim, K. L. (2004). Disclosing intellectual capital in company annual reports: evidence from Malaysia. Journal of Intellectual Capital, 5, 500-510.

Gratton, L., \& Ghoshal, S. (2003). Managing personal human capital: New ethos for the 'volunteer' employee. European Management Journal, 21, 1-10.

Greenberg, J. R., \& Baron, A. (2000). Behavior in organizations. Prentice- Hall.

Gui, B. (2000). Beyond Transactions: On the Interpersonal Dimension of Economic Reality. Annals of Public and Cooperative Economics, Vol. 71, Issue. 2, 139.

Guthrie, J., \& Petty, R. (2000). Intellectual capital: Australian annual reporting practices. Journal of Intellectual Capital, 1, 241-251.

Harvey, M.G., \& Lusch, R.F. (1999). Balancing the intellectual capital books: intangible liabilities. European Management Journal, 17, 29-41.

Krings, F., \& Facchin, S. (2009). Organizational Justice and Men's Likelihood to Sexually Harass: The Moderating Role of Sexism and Personality. Journal of Applied Psychology, Vol. 94, Issue. 2, 501-510. 
Lambert, E. (2003). The Impact of Organizational Justice on Correctional Staff. Journal of criminal Justice, Vol. 31, Issue. 2, 155-168.

Nahapiet, J., \& Ghoshal, S. (1998). Social capital, intellectual capital and organizational advantage. Academy of Management Review, 23, 242-266.

Ordonez de Pablos, P. (2005). Intellectual capital reports in India: lessons from a case study. Journal of Intellectual Capital, 6, 141-149.

Parnes, H. S. (1984). People power. Beverly Hills. CA: Sage Publications.

Petty, R., \& Cuganesan, S. (2005). Voluntary Disclosure of Intellectual Capital by Hong Kong Countries: Examining Size, Industry and Growth Effects over Time. Australian Accounting Review, 15, 40- 50.

Pourezat, A. (2003). Designing of policy making system for achieve to social justice. Tarbyat modares university publisher (In Persian).

Pourezat, A. \& Golipour, M. (2008). Review of structural barriers for achieve to organizational justice. Jornal of public management, 1(In Persian).

Roos, J., \& Roos, G., \& Dragonetti, N. C., \& Edvinsson, L. (1997). Intellectual Capital. London: Macmillan Business.

Sujan, A., \& Abeysekera, I. (2007). Intellectual Capital Reporting Practices of the Top Australian Firms, Australian Accounting Review, 17, 71-83.

Sveiby, K. E. (1997). The new organizational wealth: Managing and measuring knowledge-based assets. San Francisco: Barrett-Koehler Publishers.

Whiting, R. H., \& Miller, J. C. (2008). Voluntary disclosure of intellectual capital in New Zealand annual reports and the "hidden value. Journal of Human Resource Costing and Accounting, 12(1), 26-50.

Wright, P. M., \& Dunford, B. B., \& Snell, S. A. (2001). Human resources and the resource-based view of the firm. Journal of Management, 27, 701-721.

Zhang, Q., \& Gay Fung, H. (2006). China's social capital and financial performance of private enterprises. Journal of Small Business and Enterprise Development, Vol. 13, Issue. 2, 98-207.

Table 1. Pearson Correlation between organizational justice and intellectual capital with Sub-scales $(\mathrm{n}=141)$

$$
\text { Human capital Customer capital Structural capital } \begin{gathered}
\text { Intellectual } \\
\text { capital }
\end{gathered}
$$

\begin{tabular}{l|l|l|l|l}
\hline Organizational justice & $.741^{* *}$ & $.766^{* *}$ & $.702^{* *}$ & $.790^{* *}$ \\
\hline
\end{tabular}

**. Correlation is significant at the 0.01 level (2-tailed).

Table 2. Model Summary of the Regression of organizational justice on intellectual capital and its Dimensions

\begin{tabular}{c|c|c|c}
\hline R & R Square & Adjusted R Square & Std. Error of the Estimate \\
\hline $0.791^{\mathrm{a}}$ & 0.625 & 0.617 & 6.522 \\
\hline
\end{tabular}

a. Predictors: (Constant), Intellectual capital

Table 3. Regression Analysis to on organizational justice and intellectual capital and its Dimensions

\begin{tabular}{lccccc}
\hline Predictor Variable & B & Std. Error & Beta & T & Sig. \\
\hline (Constant) & 6.336 & 3.951 & - & 1.604 & .111 \\
\hline Human capital & .356 & .166 & .242 & 2.144 & .034 \\
\hline Customer capital & .425 & .097 & .443 & 4.395 & .000 \\
\hline Structural capital & .289 & .188 & .152 & 1.536 & .127 \\
\hline
\end{tabular}




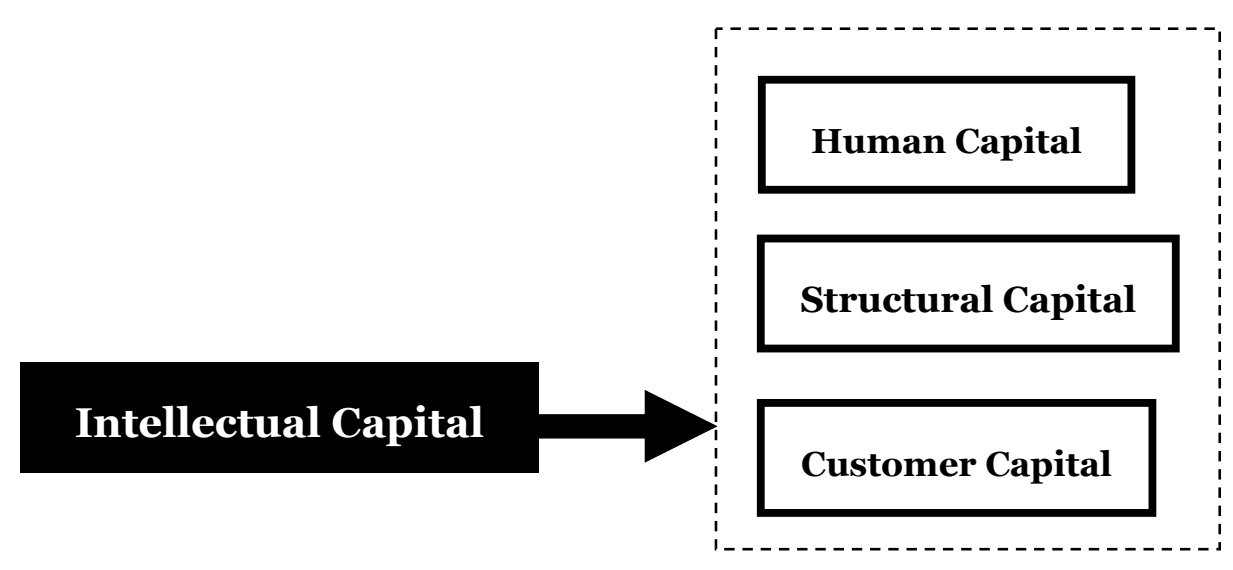

Figure 1. Dimensions of Intellectual Capital (Bontis, 2001). 